\title{
Food and the foetus and neonate
}

\section{By O. G. Brooke, Department of Child Health, St George's Hospital Medical School, Cranmer Terrace, London $S W_{17}$}

The importance of adequate growth in intra-uterine life cannot be too highly stressed. Undergrown infants may remain stunted (Sinclair \& Coldison, 1969; Beargie et al. 1970) and thus set in train a cycle of reproductive deprivation; and severely undernourished foetuses fail to achieve their full intellectual potential, as is well shown in studies on identical twins of disparate birth weight (Babson \& Phillips, 1973). Additionally, the growth of the foetus is a valuable measure of national health, and secular trends in birth weight reflect improvements in social circumstances and obstetric practices. This paper deals primarily with undernutrition in the foetus, in the first place with its identification, and secondly with some of the functional handicaps which it imposes on the neonate.

\section{Intra-uterine nutrition}

Methods for assessing the nutrition of the foetus in utero are still relatively crude, though foetal growth can now be measured accurately by ultrasound (Campbell, 1976). However, the undergrown foetus may not necessarily be undernourished, and a proportion are damaged by infection or malformation, or are simply small normal. The proper use of serial ultrasound measurements of foetal head growth and head:body values (Lunt \& Chard, 1976) may be helpful in identifying foetal malnutrition by demonstrating growth which diverges from established standards, the growth of malformed or small normal foetuses tending to remain below but parallel to the normal range (low profile growth).

Biochemical assessment of intra-uterine growth is at present limited to indirect indices of placental function, the most widely used being the maternal urinary excretion of oestrogens (Barnard \& Logan, 1972). These are produced by the secretory part of the syncytiotrophoblast and are thus a measure of placental function. Their serial estimation is useful in assessing the progress of a threatened pregnancy, but does not differentiate well between an undernourished foetus and one with reduced growth potential. However, both ultrasound measurements and serial oestrogen determinations may reflect improvements resulting from treatment in cases of impaired placental function, for example the control of hypertension.

Other biochemical estimates of placental function have been used, but are in general no more useful than oestrogens (Willocks, 1977).

Although most undernourished foetuses are primarily energy depleted, as shown by their lack of subcutaneous fat (McGowan et al. 1975) and liver glycogen (Stave, 1974), certain specific nutrient deficiencies may occur which affect foetal growth or nutritional status, and which can be diagnosed and treated antenatally. The commonest of these are severe iron and folic acid deficiency (often combined) and 
Table 1. Plasma vitamin $D$ and heat labile alkaline phosphatase ler els in Asian mothers and their infants at term (treated mothers receized $25 \mu \mathrm{g}$ (1000 I.U.) ergocalciferol daily in the last trimester)

(Values are means with their standard errors; number of subjects in parentheses)

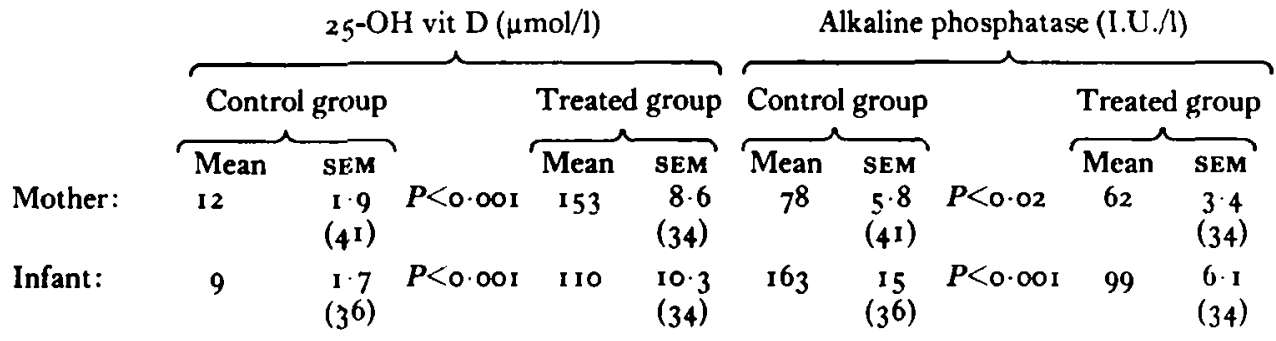

vitamin D deficiency. Maternal anaemia due to the former adversely affects foetal growth (Reinhardt, 1978 ), but the precise mechanism of this is not clear. It is not due to foetal anaemia, which is normally absent (Reinhardt, 1978), but could be due to folate deficiency, which is thought to retard postnatal growth (Gandy \& Jacobson, 1977).

Vitamin D deficiency is common in Asian immigrants in this country (Turton et al. 1977). In a recent study (Brooke, Brown et al. 1979) $40 \%$ of Asian mothers and $45 \%$ of their infants had plasma levels of $25-\mathrm{OH}$ vitamin $\mathrm{D}<5 \mathrm{nmol} / 1$ at term, and bone alkaline phosphatase levels were raised compared with a group who received treatment, indicating bone disease (Table $\mathrm{r}$ ). There was no effect on foetal growth, but neonatal rickets occurs (Ford et al. 1973), and the subsequent effects of foetal vitamin D deficiency on bone and teeth development are unknown.

\section{Nutritional status of the newborn}

Foetal malnutrition is usually presumptive and has to await the birth of the infant for its evaluation. The grossly undernourished infant presents no diagnostic dilemma, but it is a common problem to find difficulty in determining whether a small but normal looking infant has had restricted intra-uterine growth or is simply genetically small. It is important to make this distinction, not only because undernourished neonates are at risk of clinical problems such as hypoglycaemia, but also for epidemiological reasons.

A number of methods of assessing neonatal nutrition are available. These include physical features, anthropometry, biochemical indices and dynamic aspects of nutrition.

Physical examination. Examination of the nude infant is quite helpful in identifying poor nutrition. The appearance of wasting, wrinkled skin and alert vigilant gaze are characteristic of the more severe cases (Usher, 1970 ), but thinness for length in the infant of good birth weight may be more readily detected by a look at the infant than by the clinical measurements in common use.

Anthropometry. Physical anthropometry has a good deal to offer in the assessment of neonatal nutrition and, considering its relative simplicity, is 
Table 2. Birth weights of Asian and European infants in Tooting, London, $S W_{\mathrm{I} 7}(500$ infants)

(Values are means with their standard deviations)

\begin{tabular}{|c|c|c|c|c|c|c|c|c|c|c|}
\hline \multirow{3}{*}{$\begin{array}{l}\text { Gestation } \\
\text { (weeks) ... }\end{array}$} & \multicolumn{10}{|c|}{ Weight (kg) } \\
\hline & \multicolumn{2}{|c|}{37} & \multicolumn{2}{|c|}{$3^{8}$} & \multicolumn{2}{|c|}{39} & \multicolumn{2}{|c|}{40} & \multicolumn{2}{|c|}{41} \\
\hline & Mean & SD & Mean & SD & Mean & SD & Mean & SD & Mean & SD \\
\hline Asians & $2 \cdot 540$ & 0.611 & 2.990 & 0.476 & 3. 122 & 0.471 & $3 \cdot 173$ & $0.4^{86}$ & 3. 570 & 0.303 \\
\hline Europeans & $2 \cdot 926$ & 0.624 & 3.052 & 0.395 & $3 \cdot 246$ & 0.444 & 3.487 & 0.417 & 3.693 & 0.444 \\
\hline
\end{tabular}

underexploited. Measurements made on all infants in the majority of maternity departments are weight, head circumference and crown-heel length.

Weight is simple to measure and correlates with neonatal problems independently of gestation (Usher \& McLean, 1974). Thus it has been traditional to consider infants $<2.5 \mathrm{~kg}$ ('low birth weight'), to be a special high-risk group. However, an inspection of intra-uterine weight curves, e.g. those of Lubchenco et al. (1963), shows that an infant on the goth centile at 33 weeks gestation may gain no weight at all until term and still be born weighing $>2.5 \mathrm{~kg}$, which is approximately the 10 th centile at 40 weeks gestation. This infant would be severely malnourished but would not be identified as such on the basis of weight. In contrast, many normal infants, particularly Asian, are $<2.5 \mathrm{~kg}$ at term and have grown below the roth centile. Birth weight centiles for Asian infants in this country have been prepared (Grundy et al. 1978) but are not in general use. Birth weight information for Asian infants born in Tooting, a middle-class Asian district, are shown in Table 2, and confirm the reduced birth weight of these infants compared to Europeans.

Head circumference is usually measured at birth, though moulding may have reduced it by $10-20 \mathrm{~mm}$ from its potential size. It should properly be measured at the end of the first week, but rarely is. As a measure of nutritional status it ought to be useful because of the ultimate importance of brain growth. However, the correlation between brain size and performance is imperfect (Nelson \& Deutschberger, 1970) and head growth may be relatively well preserved in intrauterine malnutrition (Brandt, 1978), though usually below the 5oth centile (Babson, 1970). In 512 neonates measured at St George's Hospital, head circumference was correlated with measurements of arm fat $(r+0.40, t 3.9$, $P<0.001)$, so reduction in brain size is part of the process of attrition.

Linear measurements. Crown-heel and crown-rump lengths are hard to measure accurately and need two people to do it. Thus as routine measurements it is doubtful whether they are of any use since they are so rarely done properly. However, weight becomes more useful when assessed in relation to length (see Ponderal Index), and crown-heel length also correlates with protein deficiency, as assessed by arm muscle area, better than with measures of fat reserves (Frisancho et al. 1977). In our measurements in Tooting, the correlation with arm muscle area 
was $+0.49(P<0.001)$, and with arm fat area, +0.36 . Thus when properly done, length may contribute to the assessment of foetal protein deficiency.

It is easier to measure forearm length or knee-heel length with a small limb stadiometer (Alvear \& Brooke, 1978) than to measure crown-heel length, and one person can make the measurement unaided. In 512 neonates the correlation between forearm length and crown-heel length was $0.8 \mathrm{r}$. Foot length may be even better (James et al. 1978).

Weight:length values. Reduction in weight in relation to length is an indication of wasting as distinct from stunting and hence may be useful in assessing undernutrition of relatively short duration. Weight $\div$ (length $)^{2}$ or weight $\div$ (length) $^{3}$ (Rohrer's index) are generally used. Roord \& Ramaekers (1978) found that Rohrer's index correlated well with skinfold thickness and clinical assessment of 'malnutrition', and Davies has also used this measurement to distinguish malnourished from small normal infants (Davies et al. 1979). However, in our measurements the Ponderal Index does not correlate at all with plasma albumin, a biochemical index of acute nutrient deprivation, neither did it discriminate well between infants with other evidence of malnutrition and presumed small normal infants (Table 3 ).

Fat and muscle measurements are more direct indicators of nutritional status. Skinfold thicknesses at various sites have been used as a measure of undernutrition in neonates (Pařižkova, 1961; Gampel, 1965; Usher \& McLean, 1969; Gớnicki et al. 1972; Brans et al. 1974; McGowan et al. 1975; Frisancho et al. 1977; Roord \& Ramaekers, 1978), attempts have been made to correlate them with total body fat in infants (Dauncey \& Gairdner, 1978), and some standards are available (Oakley et al. 1977). Arm muscle and arm fat area (Frisancho, 1974; Forbes, 1978) can be calculated from mid-upper arm circumference and triceps and biceps skinfolds from the formula:

$$
\text { Muscle area }=\frac{1}{4} \pi\left[\operatorname{arm} \text { circumference }-\frac{\pi}{2}(\mathrm{~T}+\mathrm{B} \text { skinfolds })\right]^{2}
$$

Fat area is then arm area - muscle area. 'Muscle' area is more truly lean area since it includes bone. These measurements have not generally been applied to neonates, though Frisancho et al. (1977) used them to assess the influence of maternal nutrition on the newborn. Arm muscle area correlates well with total body potassium in children (J. M. Gurney and O. G. Brooke, unpublished results).

Though these measurements are relatively crude, they have the virtue of directly measuring compartments which can be expected to be affected by energy and protein depletion. If arm fat and 'muscle' area are related to arm length, an indication of the relative thinness and leanness of the arm is obtained which could be useful in determining whether small infants are malnourished (Brooke \& Butters, 1979). To test this hypothesis we measured 500 consecutive term deliveries at St George's Hospital and established ranges for arm muscle and fat area per unit arm length. We then, rather arbitrarily, decided that infants were 'malnourished' if their relative arm fat or muscle fell 2 SD or more below the mean, or if both measurements together fell more than I SD below the mean. Forty-eight infants $(9.6 \%)$ met these criteria, and we compared them with the remaining 
Table 3. Anthropometric measurements in 500 unselected neonates: birth weight, Ponderal Index and triceps skinfold in infants identified as 'malnourished' by arm anthropometry, and in all remaining infants who were <1oth weight centile but not 'malnourished'"

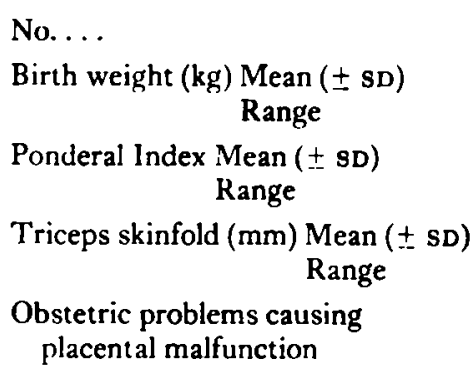

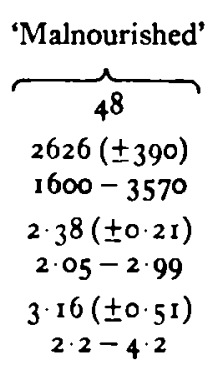

18
$<$ roth centile but

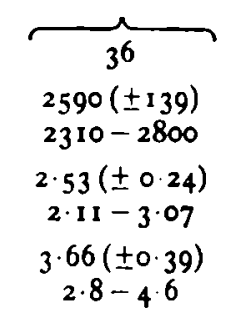

-For details, see p. 20.

infants in the cohort who were 'light-for-dates' (< roth weight centile, Gairdner's standards (Gairdner \& Pearson, 197r) but not malnourished by our criteria. The results are shown in Table 3 .

It is apparent, as we expected, that by no means all the undernourished infants fell below the roth weight centile. The incidence of obstetric complications known to cause impaired placental function (hypertension, pre-eclampsia, abruptio placentae, uterine malformations) was $37.5 \%$ in the malnourished group and $2.8 \%$ in the small-normal group. These differences were highly significant $(P<0.001)$ and support the value of this approach. Skinfold measurements and Ponderal Indices gave poorer discrimination.

Biochemical markers of nutritional status. Though widely used in assessing malnutrition in older children, biochemical indices have not generally been applied to neonates. Duodu \& Waterlow (1975) found plasma albumin and branched-chain amino acids to be the most useful indices of marginal malnutrition in rats. Both have been investigated in neonates. Hibbard and Kenna (r975) could not distinguish growth retarded from normal infants using valine:glycine values. Jacobsen et al. ( 1979) found lower plasma albumin and prealbumin in light-fordates neonates than in well-grown infants of similar gestation, but with a wide overlap. Eggermont et al. (1979) did not find prealbumin of any use in distinguishing undergrown neonates. Cord blood albumin correlated with arm fat area in our measurements $(n 84, r 0.28, P<0.02)$, but not at all with arm muscle area, Ponderal Index or head circumference. It has thus only very general relevance to nutritional assessment in this agegroup.

Other biochemical indices have been tried. Scott et al. (1975) measured transferrin, often used as an index of protein malnutrition (Antia et al. 1968), in 
cord blood of 106 babies, but found no difference between light-for-dates and wellgrown infants. Younoszai \& Haworth (r968) and Younoszai et al. (1969) showed lower hydroxyproline excretion in light-for-dates infants than in control infants of similar gestation, but with too wide a scatter to be diagnostically useful. The same problem arises in all these measurements, namely the large overlap between normal and undergrown infants which limits their usefulness.

\section{Dynamic aspects of the undergrown neonate}

Though not strictly relevant to the diagnosis of malnutrition, certain dynamic aspects of nutrition and physiological function in the undergrown neonate are so important that they merit consideration in a discussion of nutritional status in the newborn. The susceptibility of the undergrown neonate to hypoglycaemia after birth is well known and has been thoroughly investigated (Haymond et al. 1974). The aspects with which I shall deal in the remainder of this paper are concerned with nutrient absorption and retention, and with energy balance.

Nutrient absorption and retention. There is an enormous volume of literature on nutrient malabsorption in low birth weight infants, but until recently no distinction has been made between immature well-grown infants and small-fordates infants. However, there is some evidence that small-for-dates infants are deficient in digestive capacity in comparison with well-grown term infants, just as preterm infants are. Fat absorption is reduced (Melichar \& Zoula, 1973; Szotowa, Kowalczyk et al. 1974; Szotowa, Krukowa et al. 1974; Szotowa \& Kowalczyk, 1977), and in one study (Krukowa, 1977) protein digestibility was found to be lower than in well-grown infants of comparable gestation, though retention of absorbed nitrogen was high. Carbohydrate malabsorption has also been demonstrated (Ducker et al. 1978).

Energy balance. Energy balance has been less well studied in low birth weight infants than has fat and nitrogen balance, and there is little information about it in light-for-dates infants as a group. This is regrettable since growth is well correlated with energy retention in low birth weight infants (Brooke, Alvear et al. 1979).

It is uncertain whether voluntarily increased energy intake occurs in undergrown neonates. Krieger \& Whitten (1976) found that it did, but Kowalczyk's extensive studies ( 1977 ) have not confirmed their findings. However, there was a wide range of intake in Kowalczyk's infants, some consuming more than $630 \mathrm{~kJ} / \mathrm{kg}$ body-weight per $\mathrm{d}$ during their first month, and in general taking more the more underweight they were. Kowalczyk (1977) also carried out energy balances and showed no significant difference in metabolizable energy between light-for-dates and normal infants at various postnatal ages. The situation is probably different in the early neonatal period, especially in low birth weight infants, and our own studies (submitted for publication) in six light-for-dates infants of very low birth weight showed similar energy balance results in these infants and in ten preterm appropriately grown infants of similar weight, but impaired in comparison with full term infants (Table 4 ). Thus undergrown infants 
Table 4. Energy balance in preterm small-for-dates and preterm normally grown infants ( $>$ roth centile weight for gestational age)

No. ...

Mean birth weight $(\mathrm{g})$

Mean gestation at birth (weeks)

Intake $(\mathrm{kJ} / \mathrm{kg}$ per $\mathrm{d})( \pm \mathrm{SD})$

Faecal losses (kJ/kg per d) ( \pm sD)

Energy balance $(\mathrm{kJ} / \mathrm{kg}$ per d) $( \pm \mathrm{SD})$

Digestible energy $(\%)$

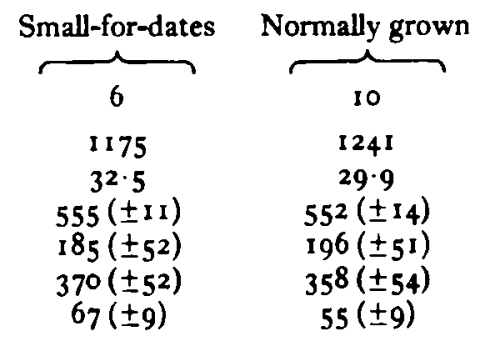

of birth weight <I $500 \mathrm{~g}$ appear to share the same digestive handicaps as the immature. However, they have an additional facet to their over-all energy balance which is not shared by well-grown, low birth weight neonates. This is their higher rate of resting metabolism (Sinclair, 1970; Alvear \& Brooke, 1977). Since their digestible energy is no greater than well-grown immature infants and their resting metabolism is higher, their efficiency of energy conversion is presumably better, as there is no evidence that they grow more slowly in the early weeks of life than normal immature infants, provided they are properly fed (Brandt, 1978). The possibility that they have an increased efficiency of energy conversion is supported by the finding that there is a reduction in the thermic effect of feeds in this group of infants (Alvear \& Brooke, 1977).

\section{Summary}

Although intra-uterine growth can be monitored effectively and postnatal size can be accurately measured, it is still difficult to differentiate between undergrown and small normal infants. Biochemical measurements are of little help, but arm anthropometry looks promising. Infants who are undergrown have certain physiological handicaps in the neonatal period, such as impaired nutrient absorption and increased resting metabolism, which add to their nutritional difficulties. More studies on the physiological differences between undergrown and normal infants may help to improve the precision with which they may be distinguished.

\section{REFERENCES}

Alvear, J. \& Brooke, O. G. (1977). F. Physiol., Lond. 275, 54 P.

Alvear, J. \& Brooke, O. G. (1978). Archs Dis. Childh. 53, 27.

Antia, A. U., McFarlane, H. \& Soothill, J. R. (1968). Archs Dis. Childh. 43, 459.

Babson, S. G. (1970). F. Pediat. 77, 11 .

Babson, S. G. \& Phillips, D. S. (1973). Nero Engl. f. Med. 290, 937.

Barnard, W. P. \& Logan, R. W. (1972). F. Obstet. Gynaec. Br. Commonw. 79, 1091.

Beargie, R. A., James, V. L. \& Green, J. W. (1970). Ped. Clin. N. Am. 17, 159.

Brandt, I. (1 978). In Human Growth, 2. Postnatal Growth, [F. Falkner and J. M. Tanner, editors] New York: Plenum.

Brans, Y. W., Summers, J. E., Dweck, H. S. \& Cassady, G. (1974). Pediat. Res. 8, 215.

Brooke, O. G., Alvear, J. \& Arnold, M. (1979). Pediat. Res. 13, 215.

Brooke, O. G., Brown, I. R. F. \& Cleeve, H. J. W. (1979). Br. Med. f. 2, 206.

Brooke, O. G. \& Butters, F. (1979). Archs Dis. Childh. 54, 16r. 
Campbell, S. (1976). In The Biology of Human Fetal Growth [D. F. Roberts and A. M. Thompson, editors]. London: Taylor \& Francis.

Dauncey, M. J. \& Gairdner, D. (1978). Archs Dis. Childh. 53, 606.

Davies, D. P., Platt, P., Pritchard, J. \& Wilkinson, P. W. (1979). Archs Dis. Childh. (In the Press).

Ducker, D. A., Hughes, C. A., Warren, I. F. \& McNeish, A. S. (1978). Archs Dis. Childh. 53, 690.

Duodu, T. A. \& Waterlow, J. C. (1975). Proc. Nutr. Soc. 34, 42 A.

Eggermont, E., Bhavani, S., Socha, J. \& Carchon, H. (1979). Acta Paed. Scand. 68, 6.3.

Forbes, G. B. (1978). In Human Growth, 2. Postnatal Grouth, [F. Falkner and J. M. Tanner, editors]. New York: Plenum.

Ford, J. A., Davidson, D. C., McIntosh, W. B., Fyfe, W. B. \& Dunnigan, M. G. (1973). Br. Med. \}. 3, 188 .

Frisancho, A. R. (1974). Am. J. clin. Nutr. 27, 1052.

Frisancho, A. R., Klayman, J. E. \& Matos, J. (1977). Am. F. clin. Nutr. 30, 704.

Gairdner, D. \& Pearson, J. (1971). Archs Dis. Childh. 46, 783.

Gampel, B. (1965). Hum. Biol. 37, 29.

Gandy, G. \& Jacobson, W. (1977). Archs Dis. Childh. 52, 7.

Gornicki, B., Dzieniszewska, L. \& Litwin, E. (1972). Probl. Med. Wieku Rozw. 13, 27.

Grundy, M. F. B., Hood, J. \& Newman, G. B. (1978). Br. F. Obstet. Gynaecol. 85, 481.

Haymond, M. W., Karl, I. E. \& Pagliara, A. S. (1974). New Engl. f. Med. 29x, 322.

Hibbard, E. D. \& Kenna, A. P. (1975). Biol. Neonate 27, 56.

Jacobsen, B. B., Peitersen, B., Andersen, H. J. \& Hummer, L. (1979). Acta Paed. Scand. 68, 49.

James, D., Dryburgh, E. \& Chiswick, M. L. (1978). Archs Dis. Childh. 53, 261.

Kowalczyk, Z. (1977). In Growth and Nutrition of Small-for-date Infants, [W. Szotowa, cditor]. Warsaw: Polish Medical Publishers.

Krieger, I. \& Whitten, C. F. (1976). Am. F. clin. Nutr. 9, 38.

Krukowa, J. (1977). In Growth and Nutrition of Small-for-date Infants, [W. Szotowa, editor]. Warsaw: Polish Medical Publishers.

Lubchenco, L. O., Hansman, C., Dressler, M. \& Boyd, E. (1963). Pediat. 32, 793.

Lunt, R. \& Chard, T. (1976). Br. F. Obstet. Gynaecol. 83, I.

McGowan, A., Jordan, M. \& McGregor, I. (1975). Biol. Neonate 25, 66.

Melichar, V. \& Zoula, J. (1973). Pädiat. Pädol. 8, 6.

Nelson, K. B. \& Deutschberger, J. (1970). Cerebr. Palsy Bull. 12, 487.

Oakley, J. R., Parsons, R. J. \& Whitelaw, A. G. L. (1977). Archs Dis. Childh. 52, 287.

Parižkova, J. (1961). Metabolism r0, 794.

Reinhardt, M. C. (1978). Helv. Paediat. Acta 33, Suppl. 41, 43.

Roord, J. J. \& Ramaekers, L. H. J. (1978). Biol. Neonate 33, 273.

Scott, P. H., Berger, H. M., Kenward, C., Scott, P. \& Wharton, B. A. (1975). Archs Dis. Childh. 50, 796.

Sinclair, J. C. (1970). Pediat. clin. N. Am. 17, 147.

Sirclair, J. C. \& Coldison, J. S. (1969). Cerebr. Palsy Bull. 11, 314.

Stave, U. (1974). New Engl. F. Med. 291, 359.

Szotowa, W. \& Kowalczyk, Z. (1977). In Growth and Nutrition of Small-for-dates Infants, [W. Szotowa, editor|. Warsaw: Polish Medical Publishers.

Szotowa, W., Kowalczyk, Z., Kleczkowska, H., Rodkiewicz, B. \& Symonowicz, H. (1974). Ped. Pol. 49, 143 .

Szotowa, W., Krukowa, A., Kowalczyk, Z., Kantoch, Z., Rodkiewicz, B., Symonowicz, H. \& Wachmic, Z. (1974). Przeg. Lek. 31, 803.

Turton, C. W. G., Stamp, T. C. B., Stanley, P. \& Maxwell, D. (1977). Lancet i, 222.

Usher, R. H. (1970). Pediat. clin. N. Am. 17, 169.

Usher, R. H. \& McLean, F. H. (1969). Y. Pediat. 74, go1.

Usher, R. H. \& McLean, F. H. (1974). In Scientific Foundations of Paediatrics, [J. Davis and ]. Dobbing, editors]. London: Heinemann.

Willocks, J. (1977). Proc. Nutr. Soc. 36, I.

Younoszai, M. K. \& Haworth, J. C. (1968). Pediat. Res. 2, 17.

Younoszai, M. K., Kacic, A., Dilling, L. \& Haworth, J. C. (1969). Archs Dis. Childh. 44, 517.

Printed in Great Britain 